\title{
IDENTIFYING THE STUDENTS' DIFFICULTIES IN COMPREHENDING TOEFL READING TEST
}

\author{
Dahlan \\ State Islamic University (UIN Alauddin Makassar), Indonesia \\ dahlanrida7279@gmail.com
}

\begin{abstract}
The study aimed to find out the Students' difficulties in comprehending TOEFL reading Test. The description of the data through the question as explained in the previous section showed that the students have some problems or difficulties in TOEFL. There are five items of the difficulties faced by students of fourth-semester students of IAIN Palopo in the Academic year 2016/2017 about determining the main idea, supporting detail, vocabulary, reference and inference. Those facts are also backed up by the result of the questionnaire which show that those items must be considered to be resolved.
\end{abstract}

Key Words: Reading Comprehension, Students' Difficulties, TOEFL Test

\section{INTRODUCTION}

English is an international language which is learned all over the word. In education English has been chosen as one of the subject that should be mastered by the student; in junior high school, senior high school, and university level. In Indonesia teaching English focuses on four basic skills, namely; listening, reading, speaking and writing, one of the fair raise skill which is very important in learning English reading. Kinds of reading which have been recognized comprehensively is become one of basic skill but it regarded as difficult one by the student. They think that reading is required a lot of vocabulary to understand the given passegges.In reading there are a few things to note, for example, punctuation in reading the text, how to capture the intent of the text, and the difficulty in understanding a passage, so that the reader can get clear information from a text that was written by an author. Moreover, a reader should pay attention word for word from the text so that use pronoun can get the meaning and purpose in reading the text.

One of them most complaints is difficulties in doing the TOEFL test that is a test of English language proficiency and become a global standard for viewing one's ability in the English language as a whole therefore, it becomes very important the understanding because TOEFL is a test used to determine ability to master English especially related to the academic purposes. TOEFL test is designed to measure the English language proficiency for those whose everyday language is not English. TOEFL is a common requirement when we want to apply for scholarship abroad or work requirement in many companies. To be able to do the TOEFL test well and get a high sore, in accordance with the allocation of time, it takes the right technique. One alternative that can be applied is difficulties in comprehending Reading 
TOEFL. When looking for details, we expect students to concentrate on the minutes of what they are reading.

By using technique the participant can cover the whole problem on the items on the TOEFL test is very varied and has a difficulty level is quite high. The writer chooses this technique because it is considered to help to plan, communicate, become more creative, save time, solve problems, focus, organize and clarify thoughts, recall them better, learn faster and efficient, and see the whole picture. Achieving a high TOEFL scores particularly in reading comprehension is often a problem for most people, especially those who are required to take the test because many students who cannot read fast and understand quickly because lack of rich vocabulary of well-established. So wealth richer vocabulary possessed the more easily achieve fast read and understand quickly. The lack of ability in comprehend the reading text, be, such as; inability in scanning, skimming, guessing meaning from the context, etc. The students unable in getting the message from the text and they will be failure in answering the question related to the text.

\section{METHODS}

The method that applied in this research was quantitative descriptive method. It is used to give description about students' difficulties in comprehending TOEFL Reading Test at fourth semester of IAIN Palopo.

\section{Design}

Design in uses research was a questionnaire distributed to students in the fourth semester of study completed S1. This questionnaire which gives data related to teaching reading TOEFL test to be resolved as a condition to determine how well the students' answer the questions that have been created. The questionnaire consisted of 50 questions and 10 types in the TOEFL.

\section{Population and Sample}

The population of this research wereall of the fourth semester students of IAIN Palopo. The number of population was 124 students from four classes. They are A, B, C, and D. Sample was a part of population that can represent all of population. In this case, the researcher applied purposive sampling, it can represent a class A in fourth semester because the English language proficiency is tolerable another classes. The researcher took 20 students in class A of IAIN Palopo.

\section{Instrument the Research}

\section{TOEFL Reading Test}

By using a TOEFL Reading test in the form of multiple choicequestionsconsistingof50 questions, that asking about the students' difficulties in IAIN Palopo. 


\section{Questionnaire}

Questionscreated by the authors is the question to the students about what the difficulties faced in working TOEFL reading test. The number of question consist 8 (eight) question and have three multiple choice namely strongly agree (SS), agree (S), and easy (M).

\section{Procedure of Collecation Data}

The procedure of the research following steps:

1. The writer explained little about TOEFL reading

2. The writer conducted test and questionnaire, and then explained how to do the test. The time for doing the test took 55 minutes and questionnaires will be taken 15 minutes.

3. The writer analyzed the result of the test and questionnaire.

4. Classified the data based on the students ability and students difficulties in TOEFL reading.

\section{Technique of Data Analysis}

In analyzing the data the writer used descriptive analyzing the data:

Test

The writer analyzed the ability of the fourth semester at IAIN Palopo in TOEFL Reading Test by using the following:

Scoring the students answer

$$
\text { Score }=\frac{\text { Total Correct Answer }}{\text { Total Test Item }} \text { X } 10
$$

Classifying the students score based on the following classification

$$
\mathrm{M}=\frac{\sum \times}{N}
$$

Where:

$$
\begin{aligned}
& M=\text { Mean Score } \\
& \sum \times=\text { Total Score } \\
& N=\text { Total Sample }
\end{aligned}
$$

Classifying the students score based on the following classification

Excellent : 9.6-10

Very good : 8.6-9.5

Good : : 7.6-8.5

Fairly good $\quad: 6.6-7.5$ 
Fairly $\quad:$ 5.6-6.5

Poor : :3.6-5.5

Very Poor : :0-3.5

Questionnaire

To analyze then responses in comprehending TOEFL reading test at fourth semester of IAIN Palopo, the writer used percentage of the questionnaire the writer used the following formula:

$$
\mathrm{P}=\frac{\mathrm{Fq}}{\mathrm{N}} \mathrm{X} 100 \%
$$

Where:

$\mathrm{P} \quad=$ Rate percentage

$\mathrm{F} \mathrm{q} \quad=$ Frequency of Respondent

$\mathrm{N}=$ Total Sample

\section{RESULTS}

TOEFL Reading Test

Table 1. The score of TOEFL Reading test

\begin{tabular}{lccc}
\hline No & Respondent & Correct answer & Score \\
\hline 1 & R1 & 23 & 4.6 \\
2 & R2 & 17 & 3.4 \\
3 & R3 & 17 & 3.4 \\
4 & R4 & 17 & 3.4 \\
5 & R5 & 18 & 3.6 \\
6 & R6 & 18 & 3.6 \\
7 & R7 & 18 & 3 \\
8 & R8 & 15 & 3 \\
9 & R9 & 15 & 3 \\
10 & R10 & 15 & 3.6 \\
11 & R11 & 18 & 3.2 \\
12 & R12 & 16 & 3 \\
\hline
\end{tabular}




\begin{tabular}{llll}
\hline 13 & R13 & 13 & 2.6 \\
14 & R14 & 13 & 2.6 \\
15 & R15 & 12 & 2.4 \\
16 & R16 & 11 & 2.2 \\
17 & R17 & 11 & 2.2 \\
18 & R18 & 11 & 2.2 \\
19 & R19 & 13 & 2.6 \\
20 & R20 & 16 & 3.2 \\
\hline
\end{tabular}

From the table 4.1, there are only 4 students who scored 4.6, 3.6, 3.6 and 3.6. The other students got very less than the maximum value. Means can be seen students still have difficulty in TOEFL reading test.

Table 2. Rate percentage of the students score in TOEFL Reading test

\begin{tabular}{lcccc}
\hline No & Classification & Score & Frequency & Percentage \\
1 & Excellent & $9.6-10$ & - & - \\
2 & Very good & $8.6-9.5$ & - & - \\
3 & Good & $7.6-8.5$ & - & - \\
4 & Fairly good & $6.6-7.5$ & - & - \\
5 & Fairly & $5.6-6.5$ & 13 & $65 \%$ \\
6 & Poor & $3.6-5.5$ & 7 & $35 \%$ \\
\hline
\end{tabular}


1. Questionnaire

Table 3. The answering question in TOEFL reading Test

\begin{tabular}{|c|c|c|c|}
\hline No & Classification & Frequency & Percentage \\
\hline 1 & Very difficult & 2 & $10 \%$ \\
\hline 2 & Difficult & 14 & $70 \%$ \\
\hline \multirow[t]{2}{*}{3} & Easy & 4 & $20 \%$ \\
\hline & Total & 20 & $100 \%$ \\
\hline
\end{tabular}

Source: number 1 questionnaire

\section{DISCUSSION}

The description of the data through question as explained in the previous section showed that the students have some problem or difficulties in TOEFL reading. Student difficulties in comprehending TOEFL reading test at fourth semester in IAIN Palopo. In reading TOEFL test, there are five items among the five items to the difficulties faced by students fourth semester class A are the supporting details, because the average student in the TOEFL test carried there are some students who go a very minimal value of item is in reading TOEFL test. As for the y difficult problem answered by students of fourth semester is IAIN Palopo:

\section{Main Idea}

33. Some scientists believe that the African bees which have devastated the Latin American beekeeping industry will be come gentler as they interbreed with the previously introduced European varieties.

a. European bees will not be advantageous to the Latin American beekeeping industry

b. African bees are ferocious and destructive

c. The Latin American beekeeping industry bees interbreed

d. African bees as well as European bees live in Latin America

37. Elephants are slowly becoming trapped in isolated forest enclaves completely surrounded by land cleared for agriculture.

a. Hunters are trapping elephant's in isolated forest enclaves to get their ivory tusks.

b. People are destroying the elephant's habitat to make farms

c. Elephant's would have to cross through farmland to migrate to different forests

d. People are trapping elephant's to use them for clearing land for agriculture

Supporting Details

44. "Medical authorities have been reluctant to support the findings of some nutritionists that vitamin $C$ given in large doses can prevent the common cold 
a. Medical authorities support the nutritionists' views about the value of vitamin $C$ in preventing the common cold

b. Nutritionists have found that medical authorities are not in favor using vitamin $C$ to prevent the common cold

c. Some nutritionists have found that large doses of vitamin $C$ doses of vitamin $C$ can prevent the common cold, but this has not been completely accepted by medical authorities

d. According to nutritionists and some medical authorities, the common cold can be prevented by giving large doses of vitamin $C^{\prime \prime}$

45. "A silver compound has been found to kill parasitic protozoa which are carried by the dreaded tsetse fly causes sleeping sickness

a. The dreaded tsetse fly causes sleeping sickness and kills the parasitic protozoa used for finding silver compound

b. It has been found that the silver compound which is carried by the dreaded tsetse fly and causes sleeping sickness kills the parasitic protozoa

c. Sleeping sickness, which is caused by the dreaded tsetse fly, has been found to kill the parasitic protozoa in silver compound

d. Parasitic protozoa which causes sleeping sickness and are carried by the dreaded tsetse fly can be killed with a silver compound"

Vocabulary

8. The false theory of spontaneous generation was disproved by Louis Pasteur
a. Sagacious
c. circumstantial
b. Automatic
d. surreptitious

Reference

13. Researchers believe that MAO (Monoamine Oxidase) in the brain has an effect on behavior by breaking down the chemical neurotransmitters that carry messages between neurons.

Scientists have found a connection between levels of MAO and adult behavior.

One study found approximately the same range of MAO levels infants and adults.
a. MAO and behavior patterns
c. one study $M A O$
b. What is $M A O$
d. MAO's effect on adults behavior

Inference

Questions 21-30

A relatively new feature of radio broadcasts in Unites States is the call-in therapy shows, in which callers get the opportunity to air problems, however intimate while the hosts offer 
line 5 them free, and immediate, advice. The started, like so many other self-help psychology ideas, in California in the early 1970's, but now they have spread to many other parts of the century and enjoy considerable popularity.

This phenomenon certainly doe not please all psychologists and the shows have line 10 become a matter of some concern to their professional association, the APA.

Presents APA guidelines merely prohibit psychologists from diagnosing problem,

line 15 or from offering psychotherapy on the radio, while the earlier ones had prohibited all giving of advice outside die traditional therapist-patient relationship. This prohibition fails to satisfy many psychologists. Some consider all giving of psychological advice

line 20 over die radio totally unacceptable, but there are others who believe there should be even more of it.

The former are typified by a hasting Center psychiatrist. Who describes the

line 24 activity as "disgusting". On one occasion, he backed up view by

line 25out of a radio program when the host insisted he answer listeners' calls. But radio therapy hosts, who are mostly attractive, youngish and qualified women, are fully capable of backing up theirs, and do so charmingly and effectively, as might be

line 30 expected from professionals combining psychological expertise with entertainment know-how.

\section{This phenomenons (line 9) refers to}

a. the fact that the shows started in California

$b$. the fact that callers air intimate problems

c. the fact that the shows started in the early 1970's

d. the fact that shows enjoy considerable popularity

The previous most of questions difficulty students choose answer $\mathrm{C}$, where as the correct answer to question no44isD. Supporting Details of matter we can see the in fourth semester students still lack of understanding of the content or context of the sentence reading in reading it. Most students rely on the ability to guess without regard to reading the text well. Besides subsequent difficulties faced by students are the main idea item, reference, and inference, where as the vocabulary items fourth semester classes a student has been able to answer well although the answer is far from perfect. There are several issues which in a sense is hard on them about the reference and the main idea.

The students difficulty in answering the questions in the test TOEFL reading is because they are lazy students read about there dingiest tool on grand the vocabulary used in the reading TOEFL rarely used so that students can only rely on guesses answer. That is why the answer TOEFL class (A) fourth semester students are still far from perfect. The others cause is the difficulty of students in findings main idea in TOEFL read; it can be seen on the table 4.9. Seven students said very difficult, ten students said difficult, and just four students said easy. It also cause of lack of student lack of speed read as seen on the table 4.10, ten students said difficult to the speed reading in TOEFL reading test. Some students also 
difficult in when reading the literature, understand the information written in the TOEFL reading test, as seen on the table 4.11, but a half of the respondent took in this research said easy to reading literature the information written after reading TOEFL test in a passage. For the question number 8, sixteen students said difficult, four students said easy, and none students' said very difficult of TOEFL reading test.

Some students are difficult in using expression when is working TOEFL reading test, it can be seen 4.8 were two students chose very difficult, nine students said difficult, and nine said easy. It means that almost a half of the students taken as sample in this research easy to use expression in TOEFL reading. From the eight questionnaires, just two questions that is most of the students said easy. It is the questionnaire number five and six easy notice the punctuation when is working or reading in TOEFL test.

\section{CONCLUSION}

Student difficulties in comprehending TOEFL reading test at fourth semester of English Department in IAIN Palopo 2014/2015 academic years in TOEFL reading are:

1. Difficulties in comprehending TOEFL reading test. In vocabulary items, the fourth semester students is much more able to answer questions TOEFL test well in the appeal other items, readings that is too long to make students become bored to read, the students on average fourth semester playing is difficulties in this item, because the vocabulary is still rarely use dignitary in every day, the students rely solely on answers guess that makes no right answer, and the items inference students almost answered with good about the test.

2. The students responses about TOEFL reading test. The researcher think there are three difficult faced by students in TOEFL reading test, namely: 1). Limited time, 2). Limited vocabulary, and 3). Lack of concentration. Therefore, in the work or answer questions TOEFL reading must use time as efficiently as possible, in addition to the students in required to reproduce in required to reproduce the vocabulary before taking the test TOEFL vocabulary before reading. Because in reading there are lot of difficult vocabulary understand and students are suggested to concentrate on the work TOEFL test.

\section{REFERENCES}

Ali, Irham, Saifuddin. (2010). 34 Trik Ampuh Capai Skor Tinggi TOEFL”, Penerbit Laksana.

Amaliah, Suci. (2012). Pengertian toefl dan soal test toefl. online : http://suciamaliah.bogspot.com/2012/09/pengertian-toefl-dan-soal-test-toefl.html

Arikunto, Suharsimi. (1992). Prosedur Penelitian Suatu Pendekatan Baru dalam Teori dan Praktek; Jakarta: PT. Rineka Cipta.

Bowman. (2014). Online: http://id.wikipedia.org/wiki/reading 
Bull, Victoria. (2008). Oxford Learners's Pocket Dictionary. Fourth Edition. NewYork: Oxford University Press

Cliffs. (2005). TOEFL preparation Guide, India: Willy-Dreamlech India pvt.Ltd.

Cristal, David. (1985) A Dictionary of Linguistics and Phonetics, New York: Basil Blackwell Lid.

David, Nunan. (1996). Language Teaching Methodology: A Textbook for Teachers. Great Britain: Redwood Books

Grallet, Fransise. (1981). Developing reading. London: Cambridge.

Harmer, Jeremy. (1998). How to Teach English. Longman: Cambridge University Press.

http://en.wikipedia.org/wiki/Reading.comprehension. Accessed on January, 20 th 2014

Inmon \& Lenier. (1992). College Reading Book 2. New York: Prentice Hall.

Malik, Afia. (2005). The Study Of Students Ability In Reading Comprehension By Using SQ3R Technique (A Case Study), Makassar: UNHAS.

Middin, Farida. (2007) The Difficulties of Students in Finding Main Idea and Supporting Details Text Reading Comprehension of the Second Years Students of English Department in STAIN Palopo. A Thesis S1. Unpublished Thesis: STAIN Palopo.

Minarti. (2009). Increasing the Students' Reading Skill at The Second Year of SMA Negeri 1 Baebunta through Anecdotes. Palopo: Uncokro Palopo.

Nuttal, Cristian. (1982). Teaching Reading Skill in Foreign Language. London: Cambridge.

Phillips, Deborah. () Longman Preparation Course for the TOEFL Test the Paper test. Pearson Longman.

Riyanto, Slamet. (2007). The $1^{\text {st }}$ Students Choice TOEFL (Test of English as a foreign Language). Pustaka Pelajar.

Ridwan. (2003). Dasar-DasarStatistika. Jakarta: Rineka Cipta.

Said, Suherniati. (2009). Difficulties Faced by The Eleventh Year Students of Madrasah Aliyah Rantebelu, Kec. Larompong in Arranging English Noun Phrase. A thesis S1. Unpublished Thesis: STAIN Palopo.

Sulpiana. (2008). The Difficulties Faced by the Second Year Students of English Program STAIN Palopo in Reading. Unpublished Thesis: STAIN Palopo.

Team of Five. (2006). Improving Reading Skill in English For University Students Book 3. 4 Workbook 3. Jakarta: Kencana 